\title{
Epithelial membrane antigen and cytokeratin expression by meningiomas: an immunohistological study
}

\author{
JM THEAKER, KC GATTER, MM ESIRI, KA FLEMING

\begin{abstract}
From the Nuffield Department of Pathology, University of Oxford, John Radcliffe Hospital, Oxford
\end{abstract}
SUMMARY Thirteen meningiomas of varying light microscopic features were studied immunohistologically using a panel of monoclonal antibodies directed against epithelial, mesenchymal, and neural components. All 13 meningiomas showed expression of epithelial membrane antigen, vimentin, and S100 protein, as did normal meninges. Five of the 13 meningiomas also showed focal expression of cytokeratins, with double labelling showing expression of cytokeratins and vimentin by different cells. The cytokeratin expression was especially noticeable in cells surrounding the hyaline bodies of meningiomas. These results provide further evidence that meningiomas have features of both mesenchymal and epithelial tissues.

Meningiomas are primary tumours thought to arise from the arachnoidal cap cell of the meninges. ${ }^{1}$ As the meninges are believed to develop from the connective tissue surrounding the neural tube, meningiomas are considered to be mesenchymal tumours. ${ }^{1}$ Meningiomas, however, show considerable heterogeneity on light microscopy ${ }^{12}$ and, indeed, can have epithelial features such as large numbers of desmosomes. ${ }^{3}$ Furthermore, occasional tumours contain periodic acid Schiff (PAS) positive hyaline bodies, which, ultrastructurally, can resemble the intracytoplasmic lumina of some adenocarcinomas, and which Kepes has suggested reflects secretory differentiation by meningioma cells. ${ }^{4}$

In this study a series of meningiomas of varying morphological patterns was examined with a panel of monoclonal antibodies, which recognises a variety of antigens of epithelial, mesenchymal, and neural type. The aim of this study was to clarify the origin of meningiomas, their relation to other cells and tissues, and to establish whether a panel of monoclonal antibodies might be useful in their differential diagnosis.

\section{Material and methods}

Thirteen cases of meningioma were recovered from the files of the neuropathology department, The Radcliffe Infirmary, Oxford, or the histopathology department, John Radcliffe Hospital, Oxford. All had been routinely fixed in formalin and embedded in paraffin wax.

Table 1 gives details of the monoclonal antibodies Accepted for publication 18 December 1985 used in this study. Peroxidase conjugated antibodies were obtained from Dakopatts.

\section{IMMUNOENZYMATIC TECHNIQUES}

Single labelled sections were stained by a three stage immunoperoxidase technique, as described previously. ${ }^{7}$ To visualise two antigens simultaneously (double labelling) slides were first stained by the immunoperoxidase technique for one antigen and then by the APAAP immunoalkaline phosphatase system for the other antigen. ${ }^{89}$

\section{Results}

Table 2 summarises the results obtained. The most striking feature was that the tumour cells of all 13 of the meningiomas, regardless of morphology, were positive for epithelial membrane antigen (EMA), shown most consistently and strongly by antibody E29. The staining was both cytoplasmic and membrane bound (Figs. 1, 2, and 3). The psammoma bodies seen in many of the tumours were, however, always negative, although the hyaline bodies in cases 3 and 4 did stain.

Five of the meningiomas were also positively labelled by at least one of the three anticytokeratin antibodies. This staining was restricted mainly to the cytoplasm of a minority of the tumour cells and was particularly noticeable in the cells surrounding the PAS positive hyaline bodies seen in cases 2,3 , and 4 (Fig. 4). The hyaline material itself was unstained. The foci showing cytokeratin expression both in the fibroblastic tumour (case 5) and the malignant menin- 
Table 1 Monoclonal antibodies used in this study

\begin{tabular}{|c|c|c|}
\hline Antibody & Specificity & Source \\
\hline 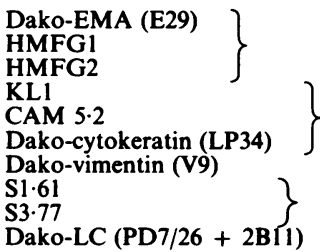 & $\begin{array}{l}\text { Epithelial membrane antigen } \\
\text { Cytokeratin intermediate filaments } \\
\text { Vimentin intermediate filaments } \\
\text { S100 protein } \\
\text { Antileucocyte common antigen }\end{array}$ & $\begin{array}{l}\text { Dakopatts a/s } \\
\text { Seward Laboratories } \\
\text { Seward Laboratories } \\
\text { Viac et al }{ }^{5} \\
\text { Becton Dickinson } \\
\text { Dakopatts a/s } \\
\text { Dakopatts a/s } \\
\text { Vanstapel et al }\end{array}$ \\
\hline
\end{tabular}

gioma (case 12) had a meningothelial growth pattern, with the predominantly fibroblastic pattern of each tumour showing no such staining.

The tumour cells of all 13 meningiomas showed cytoplasmic staining with antivimentin and two different monoclonal anti-S100 protein antibodies (S1.61 and S3.77). The cytokeratin positive cells surrounding the hyaline bodies, however, did not express vimentin (Fig. 5). This was confirmed by double labelling for cytokeratin and vimentin intermediate filaments.

Examination of normal meninges showed strong cytoplasmic staining of arachnoidal cap cells for vimentin, EMA (Fig. 6), and S100 similar to that seen in the meningioma cells. Expression of cytokeratins could not be shown in the normal leptomeninges examined.

\section{Discussion}

Meningiomas are generally considered to be of mesenchymal origin arising from the arachnoid membrane, in particular from the arachnoidal cap cells of the arachnoid granulations. ${ }^{1}$ The tumours may also have epithelial features, however, and the precise histogenesis of these tumours is controversial. ${ }^{1}$ To examine further the origin of the tumours normal meninges and 13 meningiomas of different morphological types were examined with a panel of monoclonal antibodies recognising a range of epi-

Table 2 Microscopic pattern and staining reactions of meningiomas

\begin{tabular}{|c|c|c|c|c|c|c|c|c|c|c|c|}
\hline $\begin{array}{l}\text { Case } \\
\text { No }\end{array}$ & Light microscopy & $E 29$ & $H M F G I$ & $H M F G 2$ & $K L 1$ & $\begin{array}{l}C A M \\
5 \cdot 2\end{array}$ & $L P 34$ & $S 161$ & $S 377$ & $P D 7 / 26$ & Vimentuी \\
\hline 1 & Meningothelial & ++ & ++ & + & - & - & - & ++ & ++ & - & ++ \\
\hline 2 & $\begin{array}{l}\text { Meningothelial, occasional } \\
\text { hyaline bodies }\end{array}$ & ++ & + & ++ & ++ & ++ & - & ++ & ++ & - & ++ \\
\hline 3 & $\begin{array}{l}\text { Meningothelial, occasional } \\
\text { hyaline bodies }\end{array}$ & ++ & + & $+1-$ & ++ & - & ++ & ++ & ++ & - & ++ \\
\hline 4 & $\begin{array}{l}\text { Meningothelial, plentiful hyaline } \\
\text { bodies }\end{array}$ & ++ & + & + & ++ & ++ & ++ & ++ & ++ & - & ++ \\
\hline 5 & Fibroblastic-spinal & ++ & + & + & - & - & ++ & ++ & ++ & - & ++ \\
\hline 6 & Fibroblastic & ++ & + & $+1-$ & - & - & - & ++ & ++ & - & ++ \\
\hline 7 & Psammomatous & ++ & ++ & + & - & - & - & ++ & ++ & - & ++ \\
\hline 8 & Psammomatous, spinal & ++ & + & + & - & - & - & ++ & + & - & ++ \\
\hline 9 & Angioblastic & ++ & + & + & - & - & - & ++ & ++ & ND & ++ \\
\hline 10 & Angioblastic, papillary & ++ & ++ & + & - & - & - & ++ & ++ & - & ++ \\
\hline 11 & Malignant & ++ & + & + & - & - & - & ++ & + & - & ++ \\
\hline 12 & Malignant & ++ & + & + & + & + & - & ++ & ++ & - & ++ \\
\hline \multirow[t]{2}{*}{13} & Cutaneous, scalp & ++ & ++ & ++ & - & - & - & ++ & ++ & ND & ++ \\
\hline & $\begin{array}{l}\text { Arachnoid cells of normal meninges } \\
\text { (two cases) }\end{array}$ & $+t$ & + & + & - & - & - & ++ & ++ & ND & $+t$ \\
\hline
\end{tabular}

$++=$ strong; $+=$ moderate; $+/-=$ weak; $-=$ negative; $\mathrm{ND}=$ not done. 


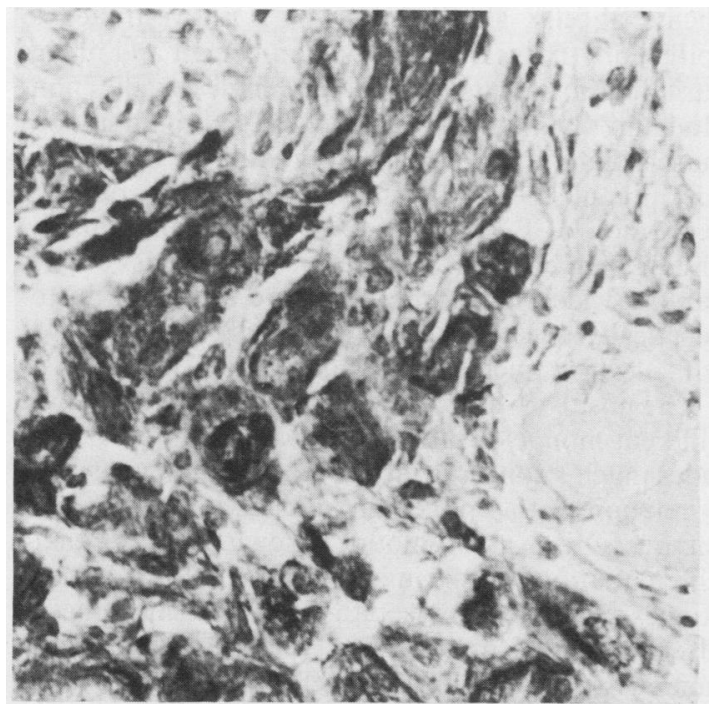

Fig. 1 Psammomatous meningioma stained with E29. (Peroxidase.) $\times 250$.

thelial and non-epithelial antigens.

We have shown vimentin expression by normal meninges, and, in accordance with previous studies, ${ }^{1011}$ all the meningiomas. As vimentin is the intermediate filament of mesenchymal cells this result can be interpreted as supporting the view that meningiomas are mesenchymal tumours arising from normal meningothelial cells. We also observed $\mathrm{S} 100$ protein expression in arachnoidal cap cells and within meningiomas, confirming its previous detection in these

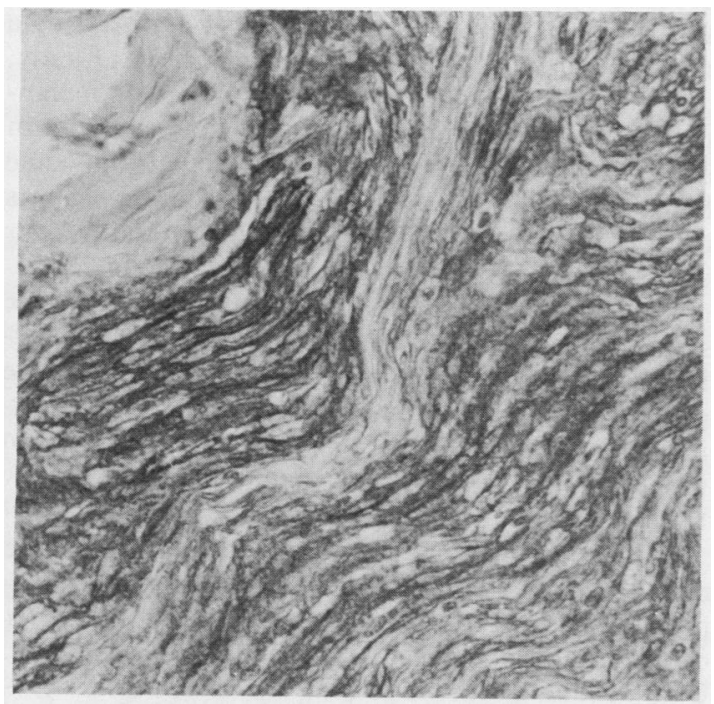

Fig. 2 Fibroblastic meningioma stained with E29.

(Peroxidase.) $\times 250$.

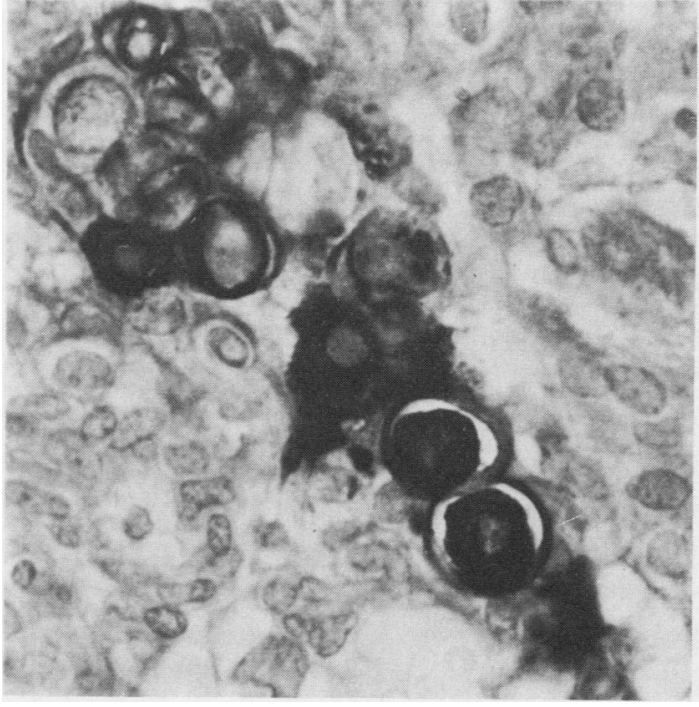

Fig. 3 Meningothelial meningioma with plentiful hyaline bodies stained with E29. Note strong staining of cells around hyaline bodies and less intense staining of cytoplasm of intervening cells. (Peroxidase.) $\times 250$.

tumours. ${ }^{12}$ The importance of this is unclear, as in our experience, $\mathrm{S} 100$ protein can be detected in a wide range of tissues and tumours, and is not specific for neuroectoderm (personal observation).

A further consistent finding, however, has been the positivity of normal meninges and all the tumours for the epithelial membrane antigen (EMA), an antigen which is widely expressed in epithelial tissues. ${ }^{13} 14$

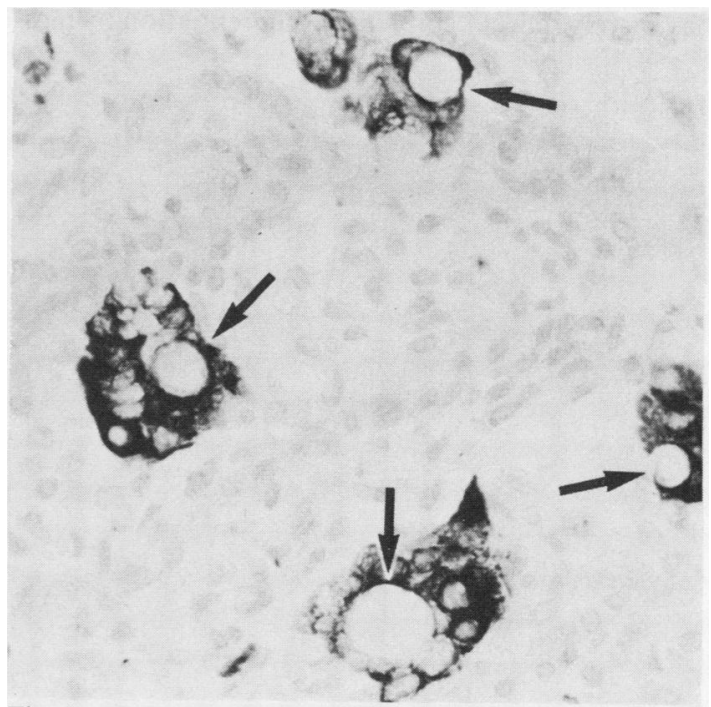

Fig. 4 Meningothelial cells around hyaline bodies (arrows) showing strong cytokeratin expression. Stained with KLI. (Peroxidase.) $\times 350$. 


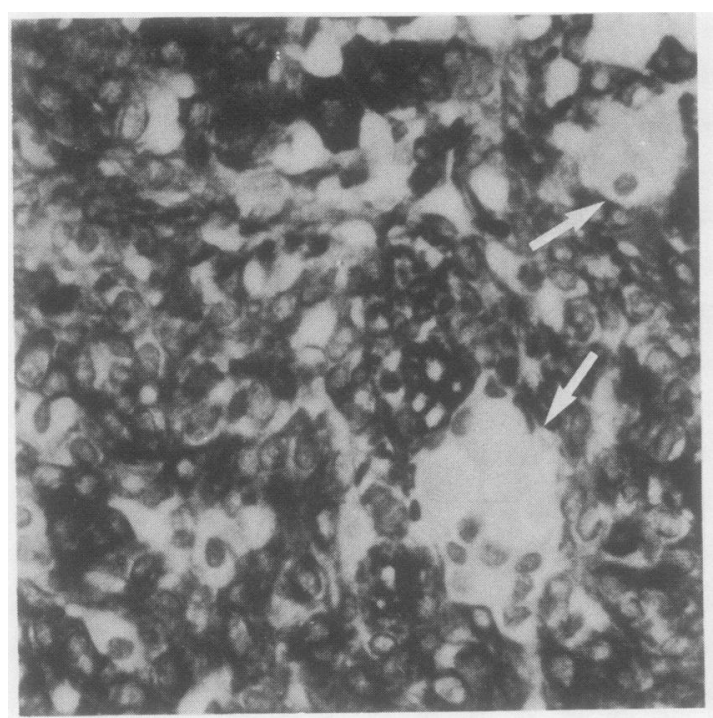

Fig. 5 Meningothelial cells around hyaline bodies (arrows) do not show vimentin expression, but remainder of tumour cells show strong expression. (Peroxidase.) $\times 400$.

The observation that both arachnoidal cap cells and meningioma tumour cells coexpress mesenchymal and epithelial markers-namely, vimentin and EMA, respectively, can be interpreted in several ways. Firstly, support could be given to the theory that there is a neuroectodermal (epithelial) contribution to the meninges and hence to some meningiomas - that is, that the tumours are truly mixed. Secondly, as meningothelial cells are highly specialised, this finding may merely reflect "epithelial" differentiation by mes-

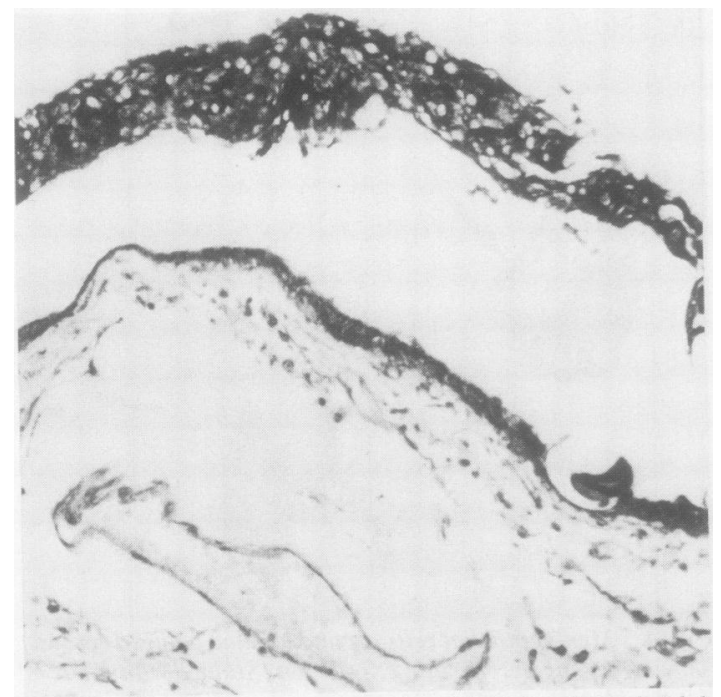

Fig. 6 Normal human arachnoid membrane and arachnidal cap cells stained with E29. (Peroxidase.) $\times 150$. enchymal cells. Thirdly, as EMA is not restricted to epithelium (it has been detected in benign and malignant plasma cells, ${ }^{14} 15$ some high grade nonHodgkin's lymphomas, ${ }^{15}$ and focally in some smooth muscle tumours (personal observation)), this observation could be a further example of non-epithelial expression of EMA. Whatever the explanation, the finding supports the view that meningiomas, despite varying widely in morphology, are a discrete histogenetically related group of tumours, which accords with electron microscopic findings. ${ }^{3}$

The positivity of five meningiomas with up to three different monoclonal anticytokeratin antibodies provides much stronger evidence that meningiomas have a relation with epithelium, either as truly mixed tumours, or as tumours showing "epithelial" differentiation. This is in keeping with ultrastructural studies that have shown epithelial like desmosomes in all patterns of menigiomas ${ }^{3}$ and intracytoplasmic lumina within meningioma cells containing hyaline bodies. ${ }^{4}$ In addition, Frank et $a l^{16}$ showed that arachnoid cells in man (the putative cells of origin of meningiomas) strongly express cytokeratins when grown in culture, while still retaining their normal ultrastructural features. A previous immunofluorescence study showed that the hyaline bodies of meningiomas contained the secretory component of IgA or IgM, a further marker of epithelial secretory cells. ${ }^{17}$

In contrast to the results presented here, most previous studies have failed to show cytokeratin expression by meningiomas. ${ }^{1011} 18$ It is unlikely that our results represent a cross reaction with desmosomal proteins (a postulated explanation ${ }^{10}$ of the only previous report of cytokeratin expression in a single meningioma ${ }^{19}$ ) for three reasons. Firstly, desmosomes are generally seen throughout all meningothelial cells, although we found that cytokeratin expression was focal and especially related to hyaline. bodies. Secondly, the staining pattern observed was cytoplasmic as well as membranous. Finally, our cases were positive with up to three different mono- $\frac{D}{0}$ clonal anticytokeratin antibodies, as opposed to the single polyclonal antibody used previously. ${ }^{19}$ Possi- N bly, the focality of cytokeratin positivity may have $N$ prevented detection in previous studies of men- N ingiomas, particularly as they relied on $\frac{\omega}{\sigma}$ immunofluorescence rather than immunoenzymatic techniques.

Expression of cytokeratin seems to be related to the meningothelial pattern of growth, although this inter- $T$ pretation should be made with caution as the number of each pattern of meningiomas studied was small. One striking observation was the relation of cyto- $\overparen{D}$ keratin expression to hyaline bodies in some tumours $\frac{\Omega}{\sigma}$ (Fig. 4). The tendency for meningothelial meningiomas to express cytokeratins may therefore be expla- 
ined by the observation that hyaline bodies are generally seen only in this pattern of meningioma. ${ }^{1}$ That some tumours express cytokeratins without apparent hyaline bodies may indicate that either cytokeratin expression is not entirely restricted to cells showing this type of differentiation or that hyaline bodies themselves are too small to be seen by light microscopy in all nests of meningothelial cells showing this type of differentiation.

There is a precedent for this finding of an epithelial component in a tumour previously thought to be mesenchymal in origin. Recently, both mesotheliomas and synovial sarcomas, tumour types also regarded as mesenchymal but with epithelial features have been shown to express vimentin, EMA, and cytokeratins. $^{20-22}$ A common feature of synovium, mesothelium, and meningeal arachnoid cells is that, although believed to be mesenchymal, they line body cavities and perform some functions equivalent to conventional epithelium. It is therefore not surprising that they, and tumours arising from them, should express markers of "epithelial" differentiation despite their mesenchymal origin. This mechanism seems a more likely explanation than the mixed tumour theory.

Although meningiomas are usually a straightforward diagnosis despite their wide range of morphological appearances, they may occasionally be difficult to distinguish from other intracranial tumours including metastases. Recent studies have suggested that metastatic carcinomas can be distinguished by their positivity for epithelial markers and lack of neural markers. ${ }^{18}$ Our results suggest caution in this interpretation and indicate consideration of meningioma with its quite different therapeutic and prognostic implications, especially if cytokeratin expression is focal. Similarly, coexpression of two classes of intermediate filaments by a tumour is an increasingly recognised observation, ${ }^{23}$ and care must be taken in the determination of the histogenesis of neoplasms based upon intermediate filament expression.

We thank Susan Jones and Helen Turley for technical help and Lesley Watts for typing the manuscript. This work was supported by the Wellcome Trust. KCG is a Wellcome Trust senior research fellow in clinical science and holds the Gillson Scholarship of the Society of Apothecaries of London.

\section{References}

${ }^{1}$ Kepes JJ. Meningiomas, biology, pathology and differential diagnosis. In: Masson monographs in diagnostic pathology. Steinberg SS, ed. New York: Masson Publishing, 1982.

${ }^{2}$ World Health Organization. Histological typing of tumours of the central nervous system. Zulch KJ, ed. Geneva: WHO, 1979.

${ }^{3}$ Napolitano L, Kyle R, Fisher R. Ultrastructure of meningiomas and the derivation and nature of their cellular components. Cancer 1964;17:233-41.

${ }^{4}$ Kepes JJ. The fine structure of hyaline inclusions (pseudopsammoma bodies) in meningiomas. $J$ Neuropathol Exp Neurol 1975;36:282-9.

${ }^{5}$ Viac J, Reano A, Brochier J, et al. Reactivity pattern of a monoclonal antikeratin antibody $(\mathrm{KLl}) . \quad J$ Invest Dermatol 1983;81:351-4.

${ }^{6}$ Vanstapel MJ, Peeters B, Cordell J, et al. Production and identification of monoclonal antibodies directed against an antigenic determinant common to the alpha and beta chain of $\mathrm{S} 100$. Lab Invest 1985;52:232-8.

${ }^{7}$ Gatter KC, Falini B, Mason DY. The use of monoclonal antibodies in histopathological diagnosis. Rec Adv Histopathol 1984;12:35-67.

${ }^{8}$ Cordell JL, Falini B, Erber WN, et al. Immunoenzymatic labeling of monoclonal antibodies using immune complexes of alkaline phosphatase and monoclonal anti-alkaline phosphatase (APAAP complexes). J Histochem Cytochem 1984;32:219-29.

${ }^{9}$ Mason DY, Abdulaziz Z, Falini B, et al. Double immunoenzymatic labelling. In: Immunocytochemistry: practical applications in pathology and biology. Polak JM, van Noorden S, eds. Bristol: J Wright, 1984:113-28.

${ }^{10}$ Schwechheimer K, Kartenbeck J, Moll R, et al. Vimentin filament-desmosome cytoskeleton of diverse types of human meningiomas. Lab Invest 1984;51:584-91.

${ }^{11}$ Ramaekers FCS, Puts JJG, Moesker O, et al. Antibodies to intermediate filament proteins in the immunohistochemical identification of human tumours: an overview. Histochem $J$ 1983;15:691-713.

${ }^{12}$ Nakamura Y, Becker LE, Marks A. Distribution of immunoreactive $\mathrm{S} 100$ protein in pediatric brain tumours. $J$ Neuropathol Exp Neurol 1983;42:136-45.

${ }^{13}$ Sloane JP, Ormerod MG. Distribution of epithelial membrane antigen in normal and neoplastic tissues and its value in diagnostic tumor pathology. Cancer 1981;47:1786-95.

${ }^{14}$ Cordell J, Richardson TC, Pulford KAF, et al. Production of monoclonal antibodies against human epithelial membrane antigen for use in diagnostic immunocytochemistry. Br J Cancer 1985;52:347-54.

${ }^{15}$ Delsol G, Gatter KC, Stein H, et al. Human lymphoid cells express epithelial membrane antigen. Lancet 1984;ii:1124-8.

${ }^{16}$ Frank EH, Burge BW, Liwnicz BH, et al. Cytokeratin provides a specific marker for human arachnoid cells grown in vitro. Exp Cell Res 1983;146:371-6.

${ }^{17}$ Budka H. Hyaline inclusions (pseudopsammoma bodies) in meningiomas: immunocytochemical demonstration of epithelial-like secretion of secretory component and immunoglobulins A and M. Acta Neuropathol 1982;56:294-8.

${ }^{18}$ Coakham HB, Garson JA, Allan PM, et al. Immunohistological diagnosis of central nervous system tumours using a monoclonal antibody panel. J Clin Pathol 1985;38:165-73.

${ }^{19}$ Nagle RB, McDaniel KM, Clark VA, et al. The use of antikeratin antibodies in the diagnosis of human neoplasms. Am J Clin Pathol 1983;79:458-66.

${ }^{20}$ Churg A. Immunohistochemical staining for vimentin and keratin in malignant mesothelioma. Am J Surg Pathol 1985;9:360-5.

${ }^{21}$ Whitaker D, Shilkin KB. Diagnosis of pleural malignant mesothelioma in life: a practical approach. $J$ Pathol 1984;143:147-75.

${ }^{22}$ Salisbury JR, Isaacson PG. Synovial sarcoma: an immunohistochemical study. J Pathol 1985; 147:49-57.

${ }^{23}$ Miettinen M, Lehto V-P, Virtanen I. Antibodies to intermediate filament proteins in the diagnosis and classification of human tumours. Ultrastruct Pathol 1984;7:83-107.

Requests for reprints to: Dr JM Theaker, Nuffield Department of Pathology, University of Oxford, John Radcliffe Hospital, Oxford, OX3 9DU, England. 